\title{
Effects of shell sand burial on seedling emergence, growth and stoichiometry of Periploca sepium Bunge
}

\author{
Tian Li* ${ }^{*}$, Jingkuan Sun ${ }^{*}$, Hongjun Yang, Jingtao Liu, Jiangbao Xia and Pengshuai Shao
}

\begin{abstract}
Background: Sand burial plays an irreplaceable and unique role in the growth and distribution of vegetation on the Shell Dike Island in the Yellow River Delta. There are still some unknown on the effects of sand burial on the morphology, biomass, and especially the stoichiometry of Periploca sepium, as well as the relationship between these factors.

Results: Shell sand burial depth had a significant influence on seedling emergence, growth, and biomass of $P$. sepium. Shallow sand burial shortened the emergence time and improved the emergence rate, morphological and biomass of P. sepium compared to deep burial and the control. Burial depth significantly affected the nitrogen $(\mathrm{N})$ and phosphorus (P) contents of the leaves. With deep burial, the carbon/nitrogen (C/N) and carbon/phosphorus (C/P) ratios decreased firstly and then increased with depth, while the nitrogen/phosphorus ratio (N/P) presented the contrary trend. Correlation analysis showed that the stoichiometry of N/P was positively correlated to morphology and biomass of $P$. sepium at different burial depths. Structural equation model analysis revealed that $N$ was the largest contributor to P. sepium biomass.
\end{abstract}

Conclusions: Optimal burial depth is beneficial to the seedling emergence, growth and nutritional accumulation of $P$. sepium. Stoichiometry has an important influence on the morphological formation and biomass accumulation.

Keywords: The Yellow River Delta, Burial depth, Seed germination, Biomass, Nutrient balance

\section{Background}

The Shell Dike Island, which locates in the southwest coast of the Bohai Sea in China, is formed by the confluence of the Yellow River and the Bohai Sea Estuary. It is the only shell dike in the world produced by the coexistence of old and new shells. The dike formed from the shells and debris of shellfish living in the intertidal zone, which has been carried by waves and deposited near the high-tide line. The wildlife resource in the dike and surrounding intertidal wetlands provides rich biological diversity and, is vital to studies of biodiversity and

\footnotetext{
*Correspondence: 912litian@163.com; sunjingkuan@126.com Shandong Provincial Key Laboratory of Eco-Environmental Science for Yellow River Delta, Binzhou University, Binzhou 256600, China
}

marine ecology [1]. Affected by human disturbance and natural environment, the ecosystem degradation of Shell Dike Island is becoming more and more serious. Therefore, it is the main measure to restore the degraded ecosystem by using vegetation. The vegetation is dominated by shrubs and herbaceous plants, and the variation in sand burial depth caused by sediment buildup in the Yellow River Estuary is the main limiting factor for plant growth [2].

Sowing and afforestation are important methods to restore the vegetation of the sandy land [3]. Compared to other areas, the sandy substrate of Shell Dike Island is easily eroded by water flow. The different burial depths influence the growth conditions of plants, such as temperature, humidity, and other physical factors [4-6].

\section{$\triangle B M C$}

(c) The Author(s). 2020 Open Access This article is licensed under a Creative Commons Attribution 4.0 International License, which permits use, sharing, adaptation, distribution and reproduction in any medium or format, as long as you give appropriate credit to the original author(s) and the source, provide a link to the Creative Commons licence, and indicate if changes were made. The images or other third party material in this article are included in the article's Creative Commons licence, unless indicated otherwise in a credit line to the material. If material is not included in the article's Creative Commons licence and your intended use is not permitted by statutory regulation or exceeds the permitted use, you will need to obtain permission directly from the copyright holder. To view a copy of this licence, visit http://creativecommons.org/licenses/by/4.0/ The Creative Commons Public Domain Dedication waiver (http://creativecommons.org/publicdomain/zero/1.0/) applies to the data made available in this article, unless otherwise stated in a credit line to the data. 
Seedling emergence is affected by many factors, but optimal sand burial depth is required for germination and excavation [7].

Carbon $(\mathrm{C})$, nitrogen $(\mathrm{N})$, and phosphorus $(\mathrm{P})$ are the three main biological elements in plants [8], and these elements are involved in numerous mutual and inseparable roles in plants [9]. Stoichiometry of these elements affects the nutrient levels, growth, and development of plants, and their integrated effects influence major ecosystem processes [10-12]. Thus, the stoichiometry of plants is of great interest not only for clarifying the distribution and utilization of plant nutrients but also for investigating the nutrient supply and demand within ecosystems $[13,14]$.

$P$. sepium, a deciduous shrub, is a dominant species with excellent medicinal value and plays an important role in the ecological protection of the Shell Dike Island. Due to human and natural factors, the distribution of $P$. sepium on the Shell Dike Island decreased. Therefore, it is important to study the physiological and ecological factors affecting $P$. sepium to protect and restore the ecology of the Shell Dike Island. Previous studies of the Shell Dike Island mainly focused on plant physiology, soil physical and chemical properties, and the biological diversity $[15,16]$. However, few studies have been conducted to investigate the stoichiometry of the dominant plants in this area, and no study has examined how the growth and biomass of P. sepium seedling could be influenced by elemental stoichiometry. Therefore, the aim of this study was to evaluate the effects of shell sand burial depth on the seedling emergence, morphology, biomass allocation, and nutrient content of $\mathrm{C}, \mathrm{N}$ and $\mathrm{P}$ in leaves. Our specific objectives were to: (i) quantify the response of seedling emergence, morphology, and biomass allocation to shell sand burial depth; (ii) determine how leaf $\mathrm{C}, \mathrm{N}, \mathrm{P}$ concentrations and the leaf $\mathrm{C}$ : N: P ratio respond to different burial depths; (iii) identify the relationships between $\mathrm{C}, \mathrm{N}, \mathrm{P}$ concentration and total biomass. Our results would provide scientific support for the coastal environmental restoration. Further, it will provide a reference for judging how the stoichiometry affect plant biomass.

\section{Results}

\section{Seedling emergence response to sand burial}

With increasing shell sand depth, the emergence rate of $P$. sepium seedlings first increased and then decreased (Fig. 1). There was a high rate of emergence under shallow burial conditions $(0-3 \mathrm{~cm})$, the highest rate of emergence of $98.9 \%$ was observed at $2 \mathrm{~cm}$, and was significantly higher than the untreated control (20.3\%, $P<0.05)$. Burial depth of $4-5 \mathrm{~cm}$ inhibited seedlings emergence, emergence rate was only $26.7 \%$ of the depth

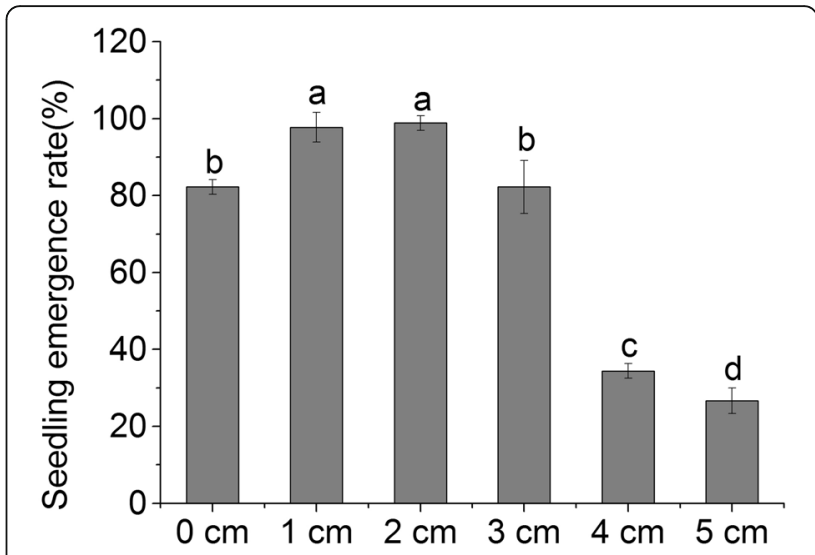

Fig. 1 Effects of different burial depths on the percentage of $P$. sepium seedling emergence. Different letters denote significant differences at $P<0.05$

of $5 \mathrm{~cm}$, which was significantly lower than the untreated control $(67.5 \%, P<0.05)$.

Burial depth had a significant influence on the seedling emergence process. Increased sand burial depth generally led to slower emergence rates (Fig. 2). The emergence speeds at $0-3 \mathrm{~cm}$ depth were faster than at 4-5 $\mathrm{cm}$ depths. At shallow burial depths, the germination numbers reached the maximum values in the 12th day, but at $4-5 \mathrm{~cm}$ depths, the maximum values occurred in the 18th day. The differences of the initial emergence time also indicated P. sepium was suitable for shallow burial depth. Burial depth significantly affected the initial emergence time of $P$. sepium seedlings (Fig. S1). The shortest emergence time was $6.7 \mathrm{~d}$ when the seeds were buried at 0 or $1 \mathrm{~cm}$. However, there was no significant difference in the initial emergence time of the shallow burial groups $(0-3 \mathrm{~cm})$. The longest initial emergence time was observed at the $4-5 \mathrm{~cm}$ depths, and was significantly longer than the control and other treatment

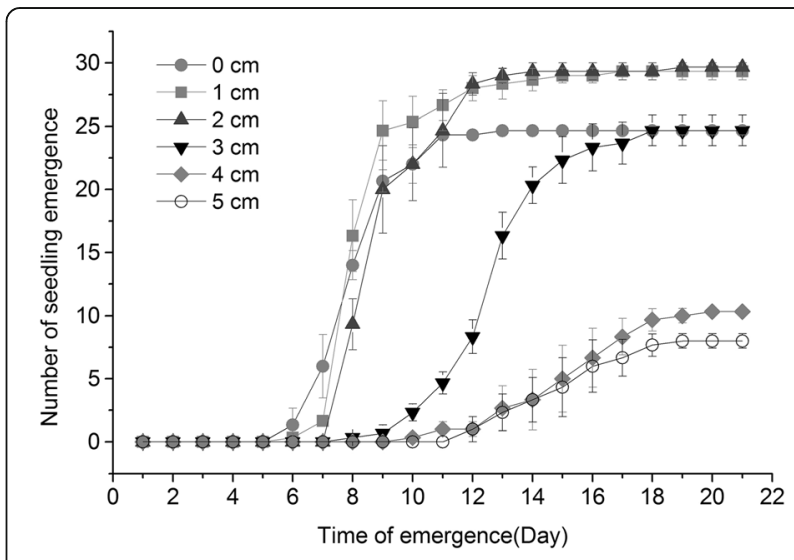

Fig. 2 Effects of different burial depths on the process of $P$. sepium seedling emergence 
groups $(P<0.05)$. These results showed that shallow sand burial was beneficial to $P$. sepium for shortening the time of first emergence.

\section{Morphology response to sand burial}

Seedling height, base diameter, leaf number, the third leaf area, root length and primary root number were measured for plants buried at different depths. Increasing shell sand burial depth initially led to increasing seedling height, but deeper burial depth resulted in decreasing height (Fig. 3a). The plant height of seedlings at $2 \mathrm{~cm}$ depth $(27.57 \mathrm{~cm})$ was significantly higher than that of the other treatment groups and the untreated control $(13.9 \mathrm{~cm})$. Plant height was the shortest at $5 \mathrm{~cm}$ burial depth, but there was no significant difference with the control group. The base diameter of the seedlings in different burial depths showed a decreasing order of $2 \mathrm{~cm}>3 \mathrm{~cm}>4 \mathrm{~cm}>1 \mathrm{~cm}=5 \mathrm{~cm}>0 \mathrm{~cm}$ (Fig. $3 \mathrm{~b}$ ), and all the treatments were significantly larger than the control. The maximum base diameter was $0.197 \mathrm{~cm}$ at $2 \mathrm{~cm}$ depth $(0.06 \mathrm{~cm}$ larger than the control group). There was no significant difference between the 1,3 , 4 , and $5 \mathrm{~cm}$ treatment groups.

The leaf characteristics of $P$. sepium varied with shell sand depth, the number of leaves initially increased with depth but decreased at larger depths (Fig. 3c). Leaf number was greatest at $1 \mathrm{~cm}$ depth (17 leaves) and smallest at $5 \mathrm{~cm}$ depth. The area of the third leaf followed the same general pattern as the number of leaves, but the differences between treatments were significant (Fig. 3d). The largest leaf area $\left(2.72 \mathrm{~cm}^{2}\right)$ was observed at $3 \mathrm{~cm}$ burial depth, but this did not differ from the $2 \mathrm{~cm}$ treatment group. The leaf area of the control group was 1.52 $\mathrm{cm}^{2}$, and did not differ from the $5 \mathrm{~cm}$ treatment group.

Burial depth had a significant impact on the growth of the underground part of P. sepium (Fig. 3e); the root length increased with the burial depth, showing a trend of $2 \mathrm{~cm}>3 \mathrm{~cm}>1 \mathrm{~cm}>5 \mathrm{~cm}>4 \mathrm{~cm}>0 \mathrm{~cm}$. The root lengths of all treatments were significantly longer than that of the control group. The longest root length $(36.77 \mathrm{~cm})$ was observed in the $2 \mathrm{~cm}$ group. The number of primary roots increased with burial depth and the numbers in all the treatment groups were higher than the control group (Fig. 3f). The $0 \mathrm{~cm}$ treatment group had the lowest number of primary roots, while the $2 \mathrm{~cm}$ group had the most $(n=5)$.

\section{Biomass and biomass allocation response to sand burial}

The effects of different shell sand burial depths on $P$. sepium dry weight were shown in Table 1 . The root and
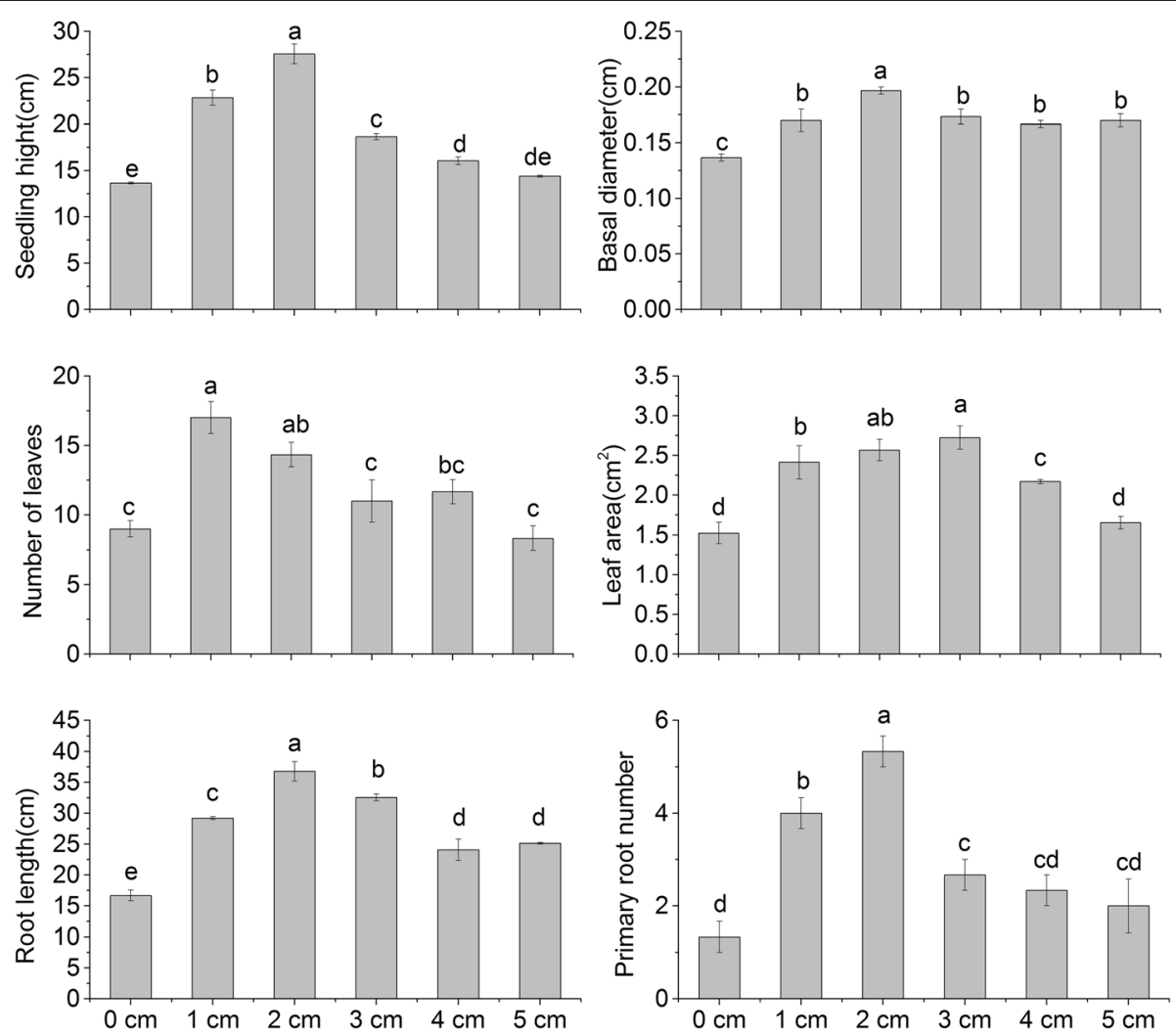

Fig. 3 Effects of different burial depths on the height (a), basal diameter (b), number of leaves (c), area of third leaf (d), root length (e) and primary root number (f) of $P$. sepium seedlings. Different letters denote significant differences at $P<0.05$ 
Table 1 Effects of different burial depths on P. sepium dry weights of different organs

\begin{tabular}{lllllll}
\hline Depth of shell sand $(\mathrm{cm})$ & 0 & 1 & 2 & 3 & 4 & 5 \\
\hline Dry weight of root $(\mathrm{g})$ & $0.130 \pm 0.006^{\mathrm{d}}$ & $0.287 \pm 0.019^{\mathrm{b}}$ & $0.393 \pm 0.015^{\mathrm{a}}$ & $0.270 \pm 0.012^{\mathrm{b}}$ & $0.213 \pm 0.015^{c}$ & $0.150 \pm 0.006^{\mathrm{d}}$ \\
Dry weight of stem(g) & $0.068 \pm 0.004^{c}$ & $0.113 \pm 0.007^{\mathrm{b}}$ & $0.260 \pm 0.006^{\mathrm{a}}$ & $0.107 \pm 0.007^{\mathrm{b}}$ & $0.090 \pm 0.015^{c}$ & $0.075 \pm 0.003^{c}$ \\
Dry weight of leaf(g) & $0.087 \pm 0.003^{c}$ & $0.130 \pm 0.006^{\mathrm{b}}$ & $0.193 \pm 0.009^{\mathrm{a}}$ & $0.117 \pm 0.017^{\mathrm{b}}$ & $0.110 \pm 0.006^{c}$ & $0.113 \pm 0.003^{\mathrm{bc}}$ \\
\hline
\end{tabular}

Different letters indicate significant differences among burial depths within organs $(p<0.05)$

leaf dry weight first increased with depth and then decreased. The root dry weight of the $2 \mathrm{~cm}$ treatment group was the greatest, and there was no significant difference among the $1 \mathrm{~cm}$ and $3 \mathrm{~cm}, 0 \mathrm{~cm}$ and $5 \mathrm{~cm}$ groups, respectively. Similar patterns were observed for stem dry weight, and there was no significant difference in $4 \mathrm{~cm}, 5 \mathrm{~cm}$, and control groups. The values for leaf dry weight decreased in an order of $2 \mathrm{~cm}>1 \mathrm{~cm}>3 \mathrm{~cm}>$ $5 \mathrm{~cm}>4 \mathrm{~cm}>0 \mathrm{~cm}$, and there was no significant difference among the $1 \mathrm{~cm}, 3 \mathrm{~cm}$ and $5 \mathrm{~cm}$ groups, $5 \mathrm{~cm}, 4 \mathrm{~cm}$ and $0 \mathrm{~cm}$ groups, respectively.

The overall and above-ground biomass of $P$. sepium first increased with burial depth and then decreased (Fig. 4a), and different burial depths had significant effects on the biomass structure of P. sepium (Fig. 4b). In terms of biomass distribution, the leaf ratios of $P$. sepium decreased at $2 \mathrm{~cm}$ and $3 \mathrm{~cm}$, then increased at $5 \mathrm{~cm}$, but had no significant difference with control. The root ratios increased with burial depth from $1 \mathrm{~cm}$ to $4 \mathrm{~cm}$. Variation in the stem ratio was not significant except at $2 \mathrm{~cm}$ burial depth, where the stem proportion increased significantly $(p<0.05)$.

\section{Leaf C:N:P stoichiometry response to sand burial}

$\mathrm{C}, \mathrm{N}$, and $\mathrm{P}$ are the main nutrient elements of plants. The $C$ content of $P$. sepium leaves did not vary with burial depth, but the $\mathrm{N}$ and $\mathrm{P}$ contents first increased and then decreased with burial depth (Fig. 5). The $\mathrm{N}$ and $\mathrm{P}$ contents of $2 \mathrm{~cm}$ treatment group were higher than the other groups, with a value of $2.409 \%$ and $0.210 \%$, respectively. There was no significant difference in the $\mathrm{N}$ contents of plants buried at $1 \mathrm{~cm}$ and $3 \mathrm{~cm}$. At $5 \mathrm{~cm}$, the $\mathrm{N}$ content was low (1.265\%), but was not significantly different from the control group. The $\mathrm{P}$ content did not differ at $1 \mathrm{~cm}$ and $4 \mathrm{~cm}$, but was still slightly higher than the control group, and had no significant difference with the $5 \mathrm{~cm}$ group.

The stoichiometry of $\mathrm{C}, \mathrm{N}$, and $\mathrm{P}$ revealed that the $\mathrm{C} / \mathrm{N}$ and $C / P$ values in the treatment groups first decreased and then increased with burial depth (Fig. 5). $\mathrm{C} / \mathrm{N}$ varied

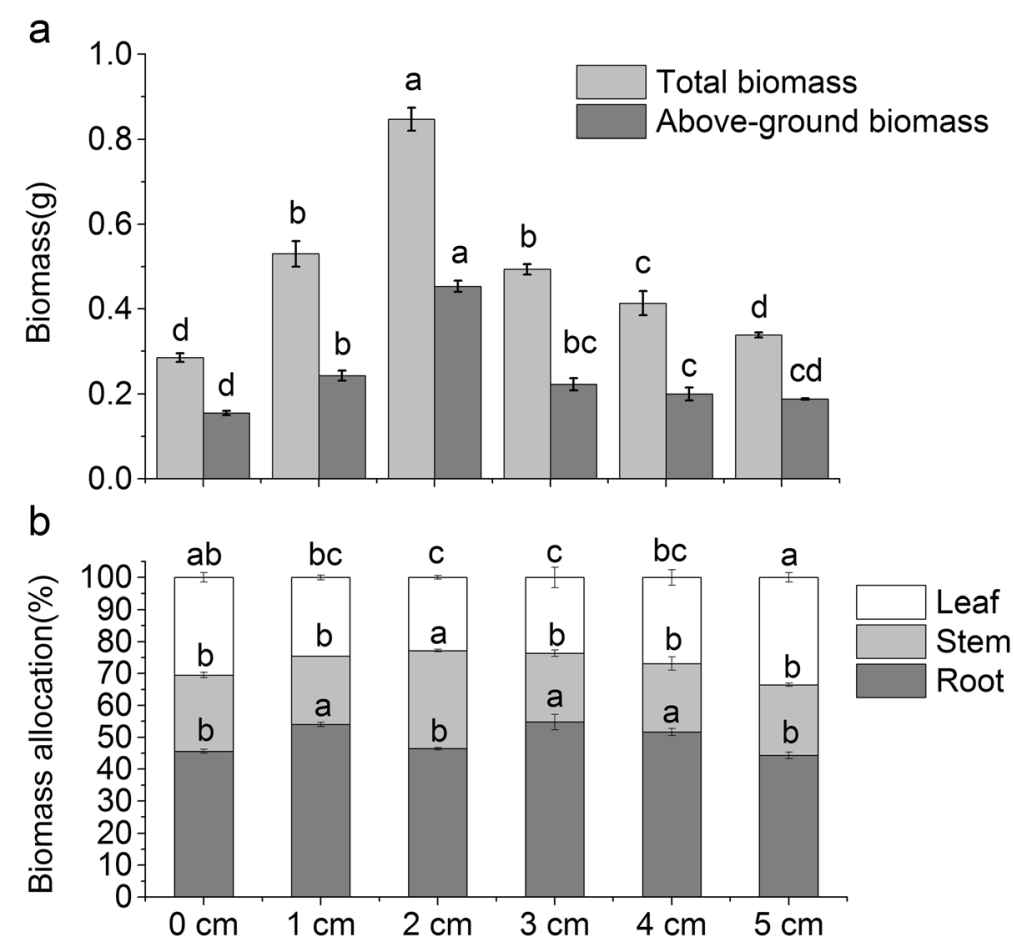

Fig. 4 Effects of different burial depths on P. sepium seedling biomass (a) and distribution (b) 

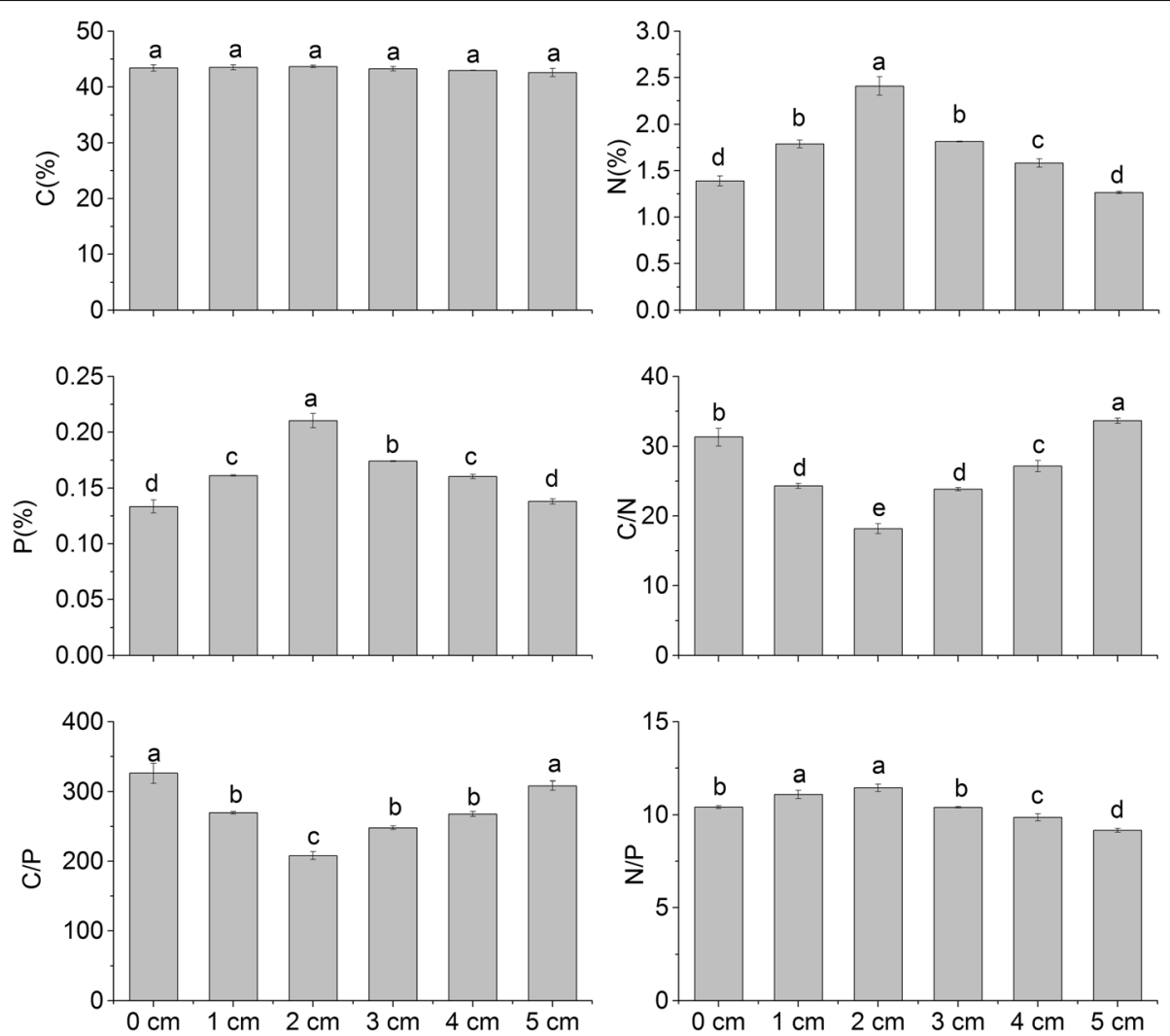

Fig. 5 Effects of different burial depths on $C, N$, and $P$ contents and $C / N, C / P$ and $N / P$ of $P$. sepium leaves

among the treatment groups, there was no significant difference between $1 \mathrm{~cm}$ and $3 \mathrm{~cm}$, but $\mathrm{C} / \mathrm{N}$ at $5 \mathrm{~cm}$ was higher than the control group. The minimum $\mathrm{C} /$ $\mathrm{N}$ and $\mathrm{C} / \mathrm{P}$ occurred in the $2 \mathrm{~cm}$ group, with a value of 18.18 and 208.06, respectively. The maximum $\mathrm{C} / \mathrm{N}$ was 33.63 at $5 \mathrm{~cm}$ depth, which was higher than the control group (2.34). The maximum value of $\mathrm{C} / \mathrm{P}$ was in the control group (326.03). The N/P differed among the treatment groups, first increased and then decreased with burial depth (Fig. 5). The smallest N/P was observed at $5 \mathrm{~cm}$, followed by the $4 \mathrm{~cm}$ group, and the highest N/P was observed at $1 \mathrm{~cm}$ and $2 \mathrm{~cm}$ depth, but the differences were not significant.

\section{Relationships between leaf nutrient traits and biomass}

There were significant correlations among the stoichiometry, seedling morphology, and biomass at different shell sand burial depths (Table 2). The $\mathrm{N}$ content of the leaves was positively correlated with the P content, and the contents of $\mathrm{N}$ and $\mathrm{P}$ were significantly positively correlated with seedling morphology and biomass index. The increases in leaf $\mathrm{N}$ and $\mathrm{P}$ contents were related to an increase in total and above-ground biomass, and promoted seedling morphogenesis. $\mathrm{C} / \mathrm{N}$ and $\mathrm{C} / \mathrm{P}$ were negatively correlated with the above mentioned morphological and biomass characters while N/P was positively correlated with all of the measurements except base diameter. The results indicated that the stoichiometry of the $P$. sepium leaves influenced the morphogenesis and biomass accumulation of P. sepium seedlings at different burial depths.

The correlation coefficients of the measurements showed that the $\mathrm{N}$ content of the leaves had a stronger effect on the leaf number, stem and root dry weights, primary root number and plant height than P. Correspondingly, $\mathrm{P}$ was a stronger indicator of seedling morphological characters such as the third leaf area, leaf dry weight and base diameter. However, N and P had similar correlation coefficients for total and above-ground biomass. The close relationships between stoichiometry, seedling morphology and biomass suggested that there were differences in nutrient utilization at different burial depths, which may be a positive response to sand stress. The stoichiometry of the leaf may be the major factor influencing $P$. sepium growth and development at different depths.

The relationships between the $\mathrm{C}, \mathrm{N}$, and $\mathrm{P}$ contents, total biomass and burial depth were further analyzed by structural equation model (Fig. 6). It is remarkable that burial depth can indirectly affect total biomass by influencing the contents of $\mathrm{C}, \mathrm{N}$, and $\mathrm{P}$ in the leaves. Burial depth had no significant effect on the P content, but significantly affected $\mathrm{C}$ and $\mathrm{N}$. However, there was no 


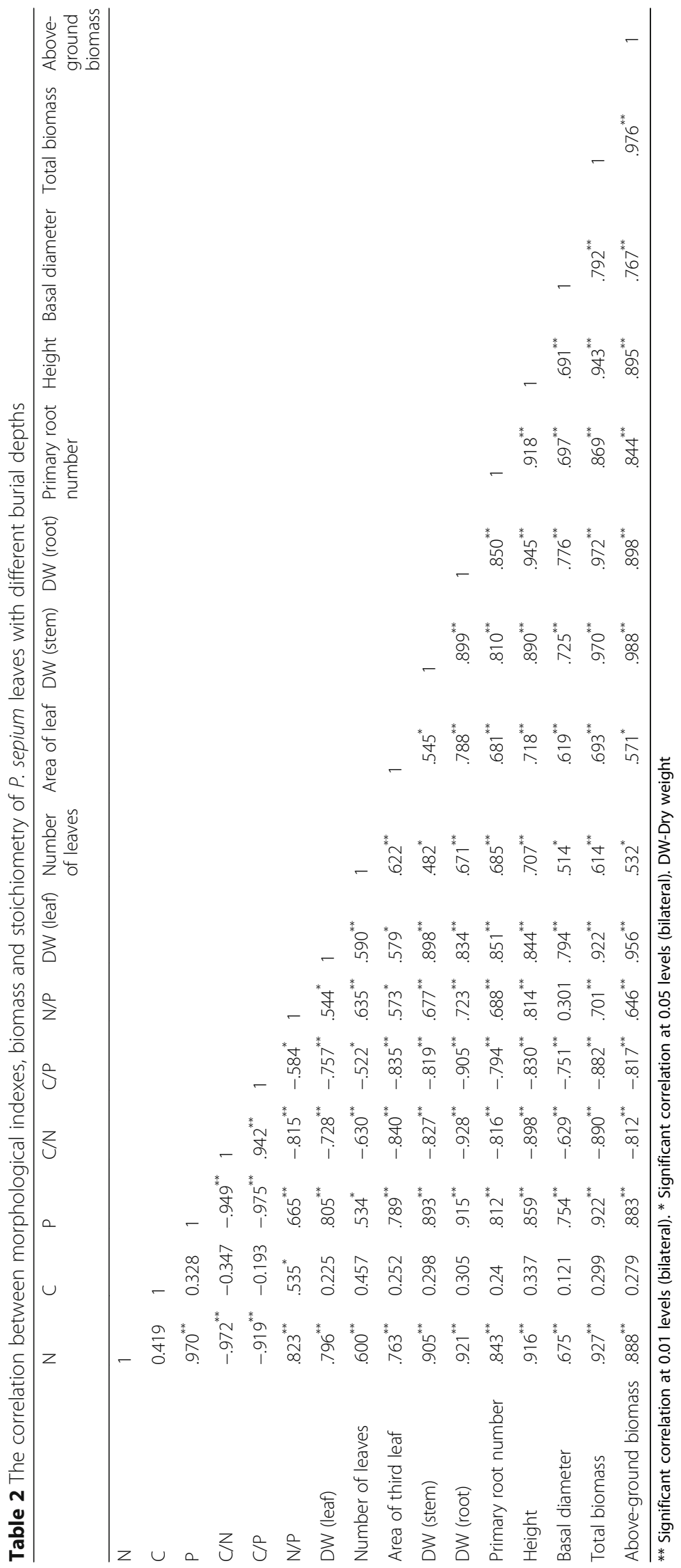




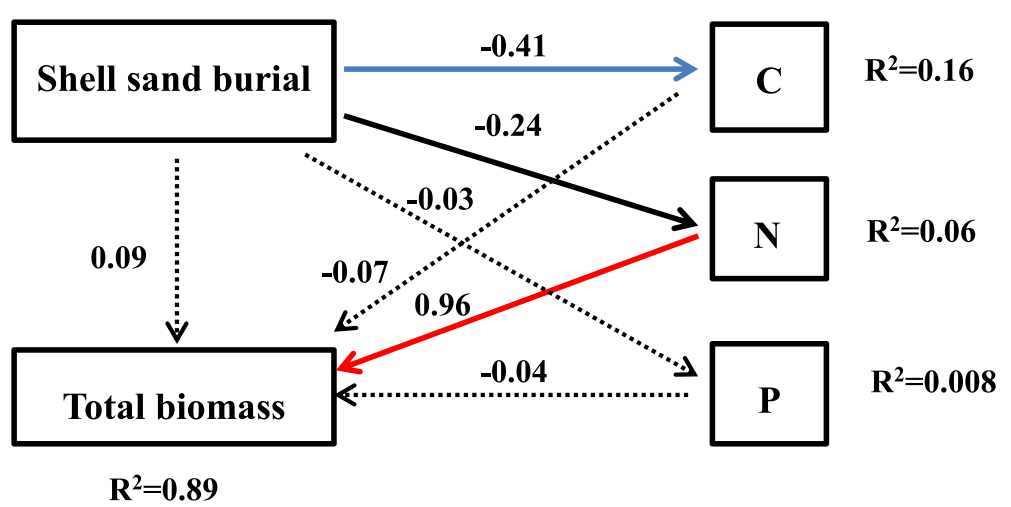

Fig. 6 Path diagrams showing the relationships between burial depth, total biomass and $C, N$, and $P$ contents of $P$. sepium leaves (Black Solid paths are statistically different at $P<0.05$, blue Solid paths are statistically different at $P<0.01$, red paths are statistically different at $P<0.001$, dashed lines indicate non-significant at $P>0.05$ )

significant effect of $\mathrm{C}$ on plant biomass; only the relationship between $\mathrm{N}$ content and biomass was significant $(P<0.001)$, with a standardized path coefficient of 0.96 . This result showed that the $\mathrm{N}$ element in the leaf was the major contributor to the biomass of $P$. sepium, while $\mathrm{C}$ and $\mathrm{P}$ did not play a significant role.

\section{Discussion}

Sand burial influences the growth and distribution of vegetation on the Shell Dike Island in the Yellow River Delta, and plants have a certain tolerance limit to sand burial. If this factor does not exceed the tolerable limit of the plant, it will promote plant growth and development. However, if the burial depth exceeds tolerable limit, it will inhibit the normal growth and development of the plant [2]. Seed germination and emergence can be affected by different burial depths $[17,18]$. Seed germination and seedling emergence are vulnerable and sensitive stages in the life history of $P$. sepium, both of which are susceptible to external factors. Therefore, the experiment on the response of the seeds and seedlings to the depth of shell sand can reflect the survival, formation and distribution of $P$. sepium under shell sand burial.

The relationship between the burial depth and the rate of seed germination and seedling emergence is important for quantifying the effect of shell silt accumulation [19]. Our results are consistent with the conclusions of previous studies, where the seed germination and seedling emergence rates were higher at shallow burial depths, and the germination rate decreased with the increasing of sand burial depth, and the seedling emergence delay [20]. Seedling emergence and growth not only depend on the characteristics of the plant species, such as seed weight and size [21], but also the growing environment (i.e., light, water, temperature, soil permeability, etc.) [22-24]. The low rates of seed germination and seedling growth at deep depths observed in this study are considered to be related to similar factors. For example, the small seeds of $P$. sepium have small material energy. When buried too deep, it is impossible for the seeds to unearth properly due to energy material depletion. Previous study has shown that excessive burial depth reduced the permeability of shell sand, led to seed dormancy, and affected the formation of seedlings [25]. Deep burial decreased light intensity and temperature, both of which are unfavorable for seed germination and seedling emergence, although, seedling emergence does not vary between light and dark conditions for some plant seeds [26]. Light conditions have obvious differences in the morphological construction of unearthed seedlings $[22,26]$. Water plays a more important role in seed germination than light, as the water storage capacity of shell sand is poor, and evaporation leads to low water content at the surface. The water content of shell sand increases with increasing burial depth. Adequate moisture is beneficial to seed germination and seedling emergence, but too high moisture, especially when the permeability is poor, may inhibit seed respiration, and inhibit seedling emergence. It could also result in seed decay. The correlation analysis revealed a positive correlation between the morphology index and the NP stoichiometry of the $P$. sepium leaves under sand burial, indicating that the stoichiometry of the leaves also played an important role in seedling morphology. This role may be very significant due to the fact that variation in the burial depths changed the microenvironment at the time of seedling emergence, and that seeds are sensitive and critical to changes in environmental conditions, and thus, affecting the morphogenesis of seedlings.

Sand thickness has an important influence on the biomass distribution of plant seedlings [27]. The results presented here showed that the proportion of leaf biomass reduced and then increased with increasing of shell sand depth, while the proportion of underground biomass 
increased and then decreased. Interestingly, the seedlings had the largest total biomass at $2 \mathrm{~cm}$ depth, but their underground ratio was similar to plants grown at $5 \mathrm{~cm}$ and $0 \mathrm{~cm}$, which had the lowest total biomass. It is due to the fact that the above-ground biomass of $P$. sepium is distributed more to the stem when buried at $2 \mathrm{~cm}$, resulting in an increase in above-ground biomass and a decrease in the proportion of below-ground biomass. This is consistent with studies which showed that sand burial changed the biomass distribution of seedlings and induced seedlings to allocate more resources to the above-ground or below-ground parts. For example, sand burial can reduce the biomass ratio of Nitraria sphaerocarpa on the ground and increase the biomass ratio of underground roots [28]. In Scaevola plumieri, sand burial improves stem growth and the replacement of leaf area [29]. However, Shi et al. found that different sand burial depths did not significantly affect the distribution of above and below ground biomass in eucalyptus seedlings [30]. These studies suggest that there are differences in the biomass distribution mechanisms caused by burial depth, reflecting different ecological strategies of plant adaptation. This is attributed to the characteristics of the species and the specific environmental conditions [29].

During plant growth and development, the accumulation of biomass is inseparable from the contents of $\mathrm{C}, \mathrm{N}$, and $\mathrm{P}$ [31]. In this study, variation in the $\mathrm{N}$ content of the leaves was consistent with the biomass change in different burial depths, the $\mathrm{N}$ content first increased and then decreased with depth. This relationship may enhance the photosynthetic characteristics of plants and promote the accumulation of products [31]. At the same time, the stoichiometry of a plant may reveal its adaptability to the environment. Generally, a high leaf $\mathrm{C}$ content suggests that the plant's defense ability is strong, while the $\mathrm{N}$ and $\mathrm{P}$ contents reflect the difference in the plant's ability to compete with nutrients [32]. Different sand burial depth resulted in significant variations in the contents of $\mathrm{N}$ and $\mathrm{P}$ and the ratios of $\mathrm{C} / \mathrm{N}, \mathrm{C} / \mathrm{P}$ and $\mathrm{N} / \mathrm{P}$ in P. sepium in the present study. These results showed that burial depth had a significant effect on the nutrient utilization of $P$. sepium seedlings. Although the $\mathrm{C}$ content in $P$. sepium leaves was the largest at $2 \mathrm{~cm}$ depth, the difference between the treatment groups was not significant. The contents of $\mathrm{N}$ and $\mathrm{P}$, however, first increased and then decreased with depth. At $2 \mathrm{~cm}$, the contents were the largest and the differences were significant. These results indicated that $P$. sepium regulated the $\mathrm{N}$ and $\mathrm{P}$ inputs of the leaf tissue, but not the content of $\mathrm{C}$ to ensure its normal life activities under the sand burial.

Studies have shown that $\mathrm{N}$ and $\mathrm{P}$ in plants promote photosynthesis and growth and that the contents of $\mathrm{N}$ and $\mathrm{P}$ in the leaves are closely related to the chlorophyll content [33]. $\mathrm{N}$ or P deficits can inhibit the activity of the optical system in chloroplast cells, resulting in light oxidation stress and photo-suppression reaction [34]. There were strong, positive correlations between biomass and $\mathrm{N}$ and $\mathrm{P}$ contents of the P. sepium leaves. The changes of biomass and $\mathrm{N}$ and $\mathrm{P}$ content were similar with depth. The above indexes reached their maximum values at $2 \mathrm{~cm}$ depth, indicating that this is the optimal depth for biomass accumulation and nutrient utilize. Other studies have shown that stoichiometry affected the distribution of plant biomass, high $\mathrm{N}$ content can increase leaf photosynthesis, increase the accumulation of assimilation products, and significantly reduce the root stem ratio $(\mathrm{R} / \mathrm{S}$; i.e., increase the proportion of biomass allocated to the upper part of the ground). Conversely, low $\mathrm{N}$ content increases the plant $\mathrm{R} / \mathrm{S}$ [35]. In this study, the stoichiometry of $P$. sepium leaves was unrelated to $\mathrm{R} / \mathrm{S}$. Thus, the stoichiometry of $P$. sepium leaves plays an important role in the accumulation of biomass during the seedling stage, but does not play a decisive role in the distribution of biomass during growth. This may be due to the fact that sand burial changes the soil microenvironment around plant roots, such as nutrient, which has an important impact on the distribution of plant biomass [36]. However, the patterns of biomass distribution during plant growth are also influenced by species and underlying genetic factor $[37,38]$.

The $\mathrm{C} / \mathrm{N}$ and $\mathrm{C} / \mathrm{P}$ of plant represent the ability of the plant to assimilate and accumulate $C$, which reflects the nutrient use efficiency of the plant body. The use of nutrient elements by plants can be reflected by its $\mathrm{C} / \mathrm{N}$ and $\mathrm{C} / P$ values [39]. The $\mathrm{C} / \mathrm{N}(22.5)$ and $\mathrm{C} / \mathrm{P}$ (232) of the $P$. sepium leaves were higher than the global average levels except the $2 \mathrm{~cm}$ burial group in the present study [40, 41]. This shows that the utilization of plant nutrient is high at all burial depths, suggesting a level of tolerance to sand burial. Slightly lower $\mathrm{C} / \mathrm{N}$ and $\mathrm{C} / \mathrm{P}$ at $2 \mathrm{~cm}$ depth may be contributed by the large biomass, prosperous growth, and great demand for nutrients in this treatment group. However, the limited nutrients of the shell sand matrix may cause nutrition deficits, which affect nutrient absorption. The N/P in the leaf can be used to analyze the relationship between plant growth and nutrient restriction. At all depths, the N/P of $P$. sepium leaves was less than 14 . According to the theory of nutritional restrictions [42], the growth and biomass accumulation of $P$. sepium seedlings are mainly limited by $\mathrm{N}$. Judging from the $\mathrm{N} / \mathrm{P}$ of $P$. sepium at different burial depths, the $\mathrm{N} / \mathrm{P}$ was the highest at the $1-2 \mathrm{~cm}$ depths. These results demonstrate that shell sand burial at $1-2 \mathrm{~cm}$ is the most favorable for P. sepium nutrient absorption.

The influences of different shell sand depths were investigated for seedling emergence, growth and nutrient utilization in the present study. However, we did not 
examine the dynamics of burial depth in different periods of the $P$. sepium life cycle. Future work should investigate how depth affects other stages of growth, development, and adaptation of $P$. sepium.

\section{Conclusions}

There is a direct relationship between the depth of burial and the germination of seeds and seedling emergence. The proper burial depth can provide suitable environmental conditions for the seedling emergence. The seeds may fail to emerge as lack of oxygen or excessive mechanical resistance when the burial depth is too great. The depth of burial not only affects seedling emergence, growth and morphology, but also the seedling's absorption of nutrient elements. The results of this study demonstrated that (1) shallow burial $(1-2 \mathrm{~cm})$ was conducive to seedling emergence, as emergence rate decreased with increasing depth. (2) The morphological characters and biomass of $P$. sepium showed similar patterns of variation with increasing shell sand burial depth. The leaf ratio of $P$. sepium first decreased and then increased with depth, while the root ratio showed the opposite pattern, and the stem ratio did not vary except at $2 \mathrm{~cm}$ depth. (3) The $\mathrm{C}$ content of the leaves did not change with increasing depth, but the $\mathrm{N}$ and $\mathrm{P}$ contents initially increased and then decreased. The contents of $\mathrm{N}$ and $\mathrm{P}$ in the leaves increased first and then decreased. The $\mathrm{C} /$ $\mathrm{N}$ and $\mathrm{C} / \mathrm{P}$ first decreased and then increased with depth. The opposite pattern was observed for N/P. (4) There was a strong correlation between the stoichiometry of the P. sepium leaves and the seedling morphogenesis and biomass, indicating that the stoichiometry was an important factor in P. sepium seedlings morphogenesis and biomass accumulation. The study of stoichiometry and growth adaptation of the dominant plants on the Shell Dike Island under sand burial is of great importance to coastal environmental restoration efforts.

\section{Methods}

\section{Experimental materials}

P. sepium seeds and shell sand were collected from May to October 2016 at the Shell Island and the National Nature Reserve in Binzhou (N $38^{\circ} 13$ '40.4' ', E $117^{\circ} 56^{\prime}$ $\left.43.7^{\prime \prime}\right)$. The seeds were collected in the experimental area of the Shell Dike Island. P. sepium is a deciduous shrub of the Asclepiadaceae family according to the Flora of China, which was formally identified by Professor Jingkuan Sun in our laboratory. The experimental techniques and plant materials used were strictly adhere to regulations of the People's Republic of China on nature reserves. Ripe $P$. sepium seeds were naturally dried and stored at $4{ }^{\circ} \mathrm{C}$. A voucher specimen has been deposited at the Shandong Provincial Key Laboratory of Eco-Environmental Science for Yellow River Delta,
Binzhou University (voucher No. ps ${ }^{-20,161,015}-001$ ). The shell sand was sifted to remove impurities.

\section{Experimental methods}

Thirty $P$. sepium seeds were dibbled in a plastic basin filled with shell sand for each pot. Each treatment was repeated 3 times. The depths of seed burial were $0,1,2$, 3,4 , and $5 \mathrm{~cm}$, according to the methods described by Mou et al. [43]. The seeds were cultivated in greenhouses with day and night temperature of $25 \pm 1{ }^{\circ} \mathrm{C}$ and $15 \pm 1{ }^{\circ} \mathrm{C}$ respectively. The relative humidity was maintained at $50 \pm 5 \%$. The numbers of emerging seedlings were counted every day after sowing. Ten seedlings were set in each pot 30 days after sowing. The seedlings were watered once every 2 days. The plant height and number of leaves were measured 60 days after sowing. When harvesting, three plants were selected to determine plant height, leaf number, root length, dry weight, primary root number, basal stem and the third leaf area (determined using the methods of Plaut et al. and Parida et al. [44, 45]).

After characterization of the physical parameters, the roots, stems and leaves were packed into self-sealing bags. Then, these materials were washed with distilled water and dried to constant weight. The dry weight of each part was measured and the leaves of P. sepium were fully ground to assess the $\mathrm{C}$ and $\mathrm{N}$ contents using a Vario EL III Element Analyzer (Elementar, Germany). The P content of the leaves was determined by molybdenum-antimony antispectrophotometry (perchloric acid - concentrated sulfuric acid) [46].

\section{Data analysis}

Statistical analyses were conducted using SPSS 19.0 software (SPSS Inc., USA). One-way ANOVA and Duncan multiple contrasts were conducted for significance analysis. Pearson correlation analysis was performed on the leaf stoichiometry and the morphological and biomass measurements. Structure equation model was used to analyze the relationship between depth, total biomass, and the leaf contents of $\mathrm{C}, \mathrm{N}$, and $\mathrm{P}$ by AMOS 17.0.2 software (Amos Development, Crawfordville, FL, USA). The structure equation model was tested using the maximum likelihood (ML) method and the root-meansquare-error of approximation (RMSEA) indicator was used to evaluate the model fit. Origin 9.0 software (Origin Lab Corporation, USA) was used to draw the figures.

\section{Supplementary information}

Supplementary information accompanies this paper at https://doi.org/10. 1186/s12870-020-2319-4

Additional file 1: Fig. S1. Effects of different burial depths on the first emergence time of $P$. sepium. Different letters denote significant differences at $P<0.05$. 


\section{Abbreviations}

C: carbon; C/N: carbon-nitrogen ratio; C/P: carbon-phosphorus ratio; DW: dry weight; ML: maximum likelihood; N: nitrogen; N/P: nitrogenphosphorus ratio; P: phosphorus; R/S: root stem ratio; RMSEA: rootmean-square-error-of- approximation

\section{Acknowledgements}

We thank Dr. Lianlian Zhu for dealing with samples and her assistance in laboratory work

\section{Authors' contributions}

SJK and LT conceived and designed the research. LT and YHJ performed the experiments and data analyses. LJT and XJB revised the manuscript. SPS contributed analysis tools and analyzed the data. All authors read and approved the manuscript.

\section{Funding}

This work was supported by National Nature Science Foundation of China (No.41971119, No. 41871089), Natural Science Foundation of Shandong Province (No. ZR2019MD024), and Youth Innovation and Technology Foundation of Shandong Higher Education Institutions (2019KJD010). The funding bodies provided the financial support to this research, including experimental implementation, sampling and data analysis.

\section{Availability of data and materials}

The datasets used and/or analysed during the current study are available from the corresponding author on reasonable request.

\section{Ethics approval and consent to participate}

Not applicable.

\section{Consent for publication}

Not applicable.

\section{Competing interests}

The authors declare that they have no competing interests.

Received: 18 August 2019 Accepted: 27 February 2020

Published online: 12 March 2020

\section{References}

1. Tian J, Xia J, Sun J, Liu Q, Zhang H, Zhao Y, Xie W, Zhang C, Fu R, Xie T, Li J, $\mathrm{Li}$ T. Ecological protection and restoration of shell ridge in Yellow River Delta. Beijing: Chemical Industry Press; 2011. p. 10-2.

2. Sun ZG, Mou XJ, Lin GH, Song HL, Jiang HH. Effects of sediment burial disturbance on seedling survival and growth of Suaeda salsa in the tidal wetland of the Yellow River estuary. Plant Soil. 2010;337(1-2):457-68.

3. Li Y, Wang W, Liu Z, Jiang S. Grazing gradient versus restoration succession of Leymus chinensis (Trin.) Tzvel. Grassland in Inner Mongolia. Restor Ecol. 2008;16(4):572-83.

4. Maun MA. The effects of burial by sand on survival and growth of Calamovilfa longifolia. Ecoscience. 1996;3(1):93-100

5. Lai LM, Chen LJ, Zheng MQ, Jiang LH, Zhou JH, Zheng YR, Shimizu H. Seed germination and seedling growth of five desert plants and their relevance to vegetation restoration. Ecol Evol. 2019;9(4):2160-70.

6. Mao PL, Guo LM, Gao YX, Qi L, Cao BH. Effects of seed size and sand buria on germination and early growth of seedlings for coastal Pinus thunbergii Parl. in the Northern Shandong Peninsula, China. Forests. 2019;10(3):281.

7. Fan BL, Zhao CM, Zhang XW, Sun K. Impacts of sand burial and wind erosion on regeneration and growth of a desert clonal shrub. Front Plant Sci. 2018;9:1696-708.

8. Zhang JH, Zhao N, Liu CC, Yang H, Li ML, Yu GR, Kevin W, Yu Q, He NP. C:N $P$ stoichiometry in China's forests: from organs to ecosystems. Funct Ecol. 2018:32(1):50-60.

9. Elser JJ, Fagan WF, Kerkhoff AJ, Swenson NG, Enquist BJ. Biological stoichiometry of plant production: metabolism, scaling and ecological response to global change. New Phytol. 2010;186(3):593-608.

10. Gusewell S. N.P ratios in terrestrial plants:variation and functional significance. New Phytol. 2004;164(2):243-66.
11. Moe SJ, Stelzer RS, Forman MR, Harpole WS, Yoshida T. Recent advances in ecological stoichiometry: insights for population and community ecology. Oikos. 2005;109(1):29-39.

12. Song ZL, Liu HY, Zhao FJ, Xu CY. Ecological stoichiometry of N:P:Si in China's grasslands. Plant Soil. 2014;380(1-2):165-79.

13. Liu FD, Zheng Y, Liu YH, Dong YF, Li DS, Wang MH. Stoichiometric nutrient balance of Suaeda salsa wetlands in different supratidal habitats of Tianjin, China. Hydrobiologia. 2019;827(1):3-19.

14. Liu GF, Cornwell WK, Pan X, Ye D, Liu FH, Huang ZY, Dong M, Cornelissen $J H C$. Decomposition of 51 semidesert species from wide-ranging phylogeny is faster in standing and sand-buried than in surface leaf litters: implications for carbon and nutrient dynamics. Plant Soil. 2015;396(1-2):175-87.

15. Xia JB, Zhao ZG, Fang Y. Soil hydro-physical characteristics and water retention function of typical shrubbery stands in the Yellow River Delta of China. Catena. 2017:156:315-24.

16. Zhao YY, Hu XM, Liu JT, Lu ZH, Xia JB, Tian JY, Ma JS. Vegetation pattern in Shell Ridge Island in China's Yellow River Delta. Front Earth Sci. 2015;9(3): $567-77$

17. Amini R, Gholami F, Ghanepour S. Effects of environmental factors and burial depth on seed germination and emergence of two populations of Caucalis platycarpos. Weed Res. 2017;57(4):247-56.

18. Kolář J, Kučerová A, Jakubec P, Vymazal J. Seed bank of Littorella uniflora(L.) Asch. In the Czech Republic, Central Europe: does burial depth and sediment type influence seed germination? Hydrobiologia. 2017;794(1):347-58.

19. Maun MA, Riach S. Morphology of caryopses, seedlings and seedling emergence of the grass Calamovilfa longifolia from various depths in sand. Oecologia. 1981;49(1):142-67.

20. Jarvis JC, Moore KA. Effects of seed source, sediment type, and burial depth on mixed-annual and Perennial Zostera marina L. seed germination and seedling establishment. Estuar Coasts. 2015;38(3):964-78.

21. Andersen CP, King G, Plocher $M$, Storm M, Pokhrel LR, Johnson MG, Rygiewicz PT. Germination and early plant development of ten plant species exposed to titanium dioxide and cerium oxide nanoparticles. Environ Toxicol. 2016:35(9):2223-9.

22. Wit MD, Galvão VC, Fankhauser C. Light-mediated hormonal regulation of plant growth and development. Annu Rev Plant Biol. 2016;67(1):513-37.

23. Mahmood AH, Florentine SK, Chauhan BS, McLaren DA. Influence of various environmental factors on seed germination and seedling emergence of a noxious environmental weed: green Galenia (Galenia pubescens). Weed Sci. 2016;164(3):486-94

24. Cao HB, Zhu ZC, Balke T, Zhang LQ, Bouma TJ. Effects of sediment disturbance regimes on Spartina seedling establishment: implications for salt marsh creation and restoration. Limnol Oceanogr. 2018:63(2):647-59.

25. Liu B, Jiang M, Tong SZ, Zhang WG, Zou CL, Wang B, Lu XG. Effects of burial depth and water depth on seedling emergence and early growth of Scirpus planiculmis Fr.Schmidt. Ecol Eng. 2015;87:30-3.

26. Flores J, González-Salvatierra C, Jurado E. Effect of light on seed germination and seedling shape of succulent species from Mexico. J Plant Ecol. 2016; 9(2):174-9.

27. Campbell DR, Rochefort L. Germination and seedling growth of bog plants in relation to the recolonization of milled peatlands. Plant Ecol. 2003;169(1): $71-84$.

28. Zhao WZ, Li QY, Fang HY. Effects of sand burial disturbance on seedling growth of Nitraria sphaerocarpa. Plant Soil. 2007;295(1-2):95-102.

29. Gilbert ME, Ripley BS. Biomass reallocation and the mobilization of leaf resources support dune plant growth after sand burial. Physiol Plant. 2008; 134(3):464-72

30. Shi L, Zhang ZJ, Zhang CY, Zhang JZ. Effects of sand burial on survival, growth, gas exchange and biomass allocation of Ulmus pumila seedlings in the Hunshandak Sandland. China Ann Bot-London. 2004;94(4):553-60.

31. Liu T, Ren T, White PJ, Cong RH, Lu JW. Storage nitrogen co-ordinates leaf expansion and photosynthetic capacity in winter oilseed rape. J Exp Bot 2018;69(12):2995-3007

32. Varma V, Catherin AM, Sankaran M. Effects of increased $N$ and $P$ availability on biomass allocation and root carbohydrate reserves differ between $\mathrm{N}$-fixing and non-N-fixing savanna tree seedlings. Ecol Evol. 2018;8(16):8467-76.

33. Cate TM, Perkins TD. Chlorophyll content monitoring in sugar maple (Acer saccharum). Tree Physiol. 2003:23(15):1077-9.

34. Li PL, Weng JY, Zhang QZ, Yu LY, Yao Q, Chang LY, Niu QL. Physiological and biochemical responses of Cucumis melo L. chloroplasts to lowphosphate stress. Front Plant Sci. 2018;9:1525-37. 
35. Xiao Y, Tao Y, Zhang YM. Biomass allocation and leaf stoichiometric characteristics in four desert herbaceous plants during different growth periods in the Gurbantunggut Desert, China. Chinese Journal of plant ecology. 2014;38(9):929-40.

36. Maun MA. Adaptations enhancing survival and establishment of seedlings on coastal dune systems. Vegetatio. 1994;111(1):59-70.

37. Craine JM, Wedin DA, Chapin FS III, Reich PB. The dependence of root system properties on root system biomass of 10 north American grassland species. Plant Soil. 2003;250(1):39-47.

38. Neumann K, Zhao YS, Chu JT, Keilwagen J, C. Reif J, Kilian B. Genetic architecture and temporal patterns of biomass accumulation in spring barley revealed by image analysis. BMC Plant Biol. 2017;17:137-48.

39. Wang M, Murphy MT, Moore TR. Nutrient resorption of two evergreen shrubs in response to long-term fertilization in a bog. Oecologia. 2014; 174(2):365-77.

40. Elser JJ, Fagan WF, Denno RF, Dobberfuhl DR, Folarin A, Huberty A, Interlandi S, Kilham SS, McCauley E, Schulz KL, Siemann EH, Sterner RW. Nutritional constraints in terrestrial and freshwater food webs. Nature. 2000; 408(6812):578-80.

41. Reich PB, Oleksyn J. Global patterns of plant leaf $\mathrm{N}$ and $\mathrm{P}$ in relation to temperature and latitude. PNAS. 2004;101(30):11001-6.

42. Han WX, Fang JY, Guo DL, Zhang Y. Leaf nitrogen and phosphorus stoichiometry across 753 terrestrial plant species in China. New Phytol. 2005; 168(2):377-85

43. Mou XJ, Sun ZG. Effects of sediment burial disturbance on seedling emergence and growth of Suaeda salsa in the tidal wetlands of the Yellow River estuary. J Exp Mar Biol Ecol. 2011;409(1-2):99-106.

44. Plaut Z, Meinzer FC, Federman E. Leaf development, transpiration and ion uptake and distribution in sugarcane cultivars grown under salinity. Plant Soil. 2000;218(1-2):59-69

45. Parida AK, Das AB, Mittra B. Effects of salt on growth, ion accumulation, photosynthesis and leaf anatomy of the mangrove, Bruguiera parviflora. Trees. 2004;18(2):167-74.

46. Bao SD. Agrochemical analysis of soil. Beijing: China Agriculture Press; 2000. p. 268-9.

\section{Publisher's Note}

Springer Nature remains neutral with regard to jurisdictional claims in published maps and institutional affiliations.

Ready to submit your research? Choose BMC and benefit from:

- fast, convenient online submission

- thorough peer review by experienced researchers in your field

- rapid publication on acceptance

- support for research data, including large and complex data types

- gold Open Access which fosters wider collaboration and increased citations

- maximum visibility for your research: over $100 \mathrm{M}$ website views per year

At $\mathrm{BMC}$, research is always in progress.

Learn more biomedcentral.com/submissions 